\title{
Exploration on Educational Path of Socialist Core Value System in University
}

\author{
Gaohe Wang \\ Marxism Studies of Jinan University \\ Guangzhou, Guangdong, China 510632
}

\begin{abstract}
As the solid front to foster and carry forward socialist core value system, universities shall give full play to their characteristic and advantage and unceasingly expand the educational path of socialist core value system, prompt universities, teachers and college students to form concerted effort and let students benefited and satisfied.
\end{abstract}

Keywords-college students; socialist core value system; educational path

\section{INTRODUCTION}

The socialist core value system is of vital importance to prosper our country. It decides the development direction of socialism with Chinese characteristics. College students are valuable resources of human talents. It has important and profound strategic significance to promote the development of socialist cause with Chinese characteristics by teaching them socialist core value system and guiding them to inherit and fulfill socialist core value system. At present, problems exist in education of socialist core value system of Chinese universities such as few numbers of paths and insufficient "concerted effort" among these paths. To intensify the education of socialist core value system on college students, we must vigorously expand educational path and give play to concerted effort among universities, teachers and college students and let students benefited and satisfied.

\section{UNIVERSITIES SHOULD CREATE GOOD EDUCATIONAL ENVIRONMENT}

University is the main place for college students to study and live. The environment of universities directly influences the growth and future of college students. Universities should give full play to characteristic and advantage of gathering knowledge and cultivating talents and make efforts to become solid front to foster and carry forward socialist core value system and create good environment for education of socialist core value system on college students.

\section{A. Establish and Improve Related Mechanism of Socialist Core Value System Education on College Students}

Strengthening the socialist core value system construction is a major strategic task put forward by the Party to adapt to new changes in ideology and culture field and the primary task to promote the development and prosperity of socialist culture. Universities should roundly and fully realize the socialist core value system education directly relates to significant problems of "cultivate what kind of people" and "how to cultivate people", actually put socialist core value education in the prominent position and let it run through the whole process of education. To make sure the socialist core value system education on college students achieves the anticipated effects, universities need to establish and improve related mechanism and provide system guarantee for socialist core value system education on college students. Firstly, establish and improve organization mechanism. The work team of ideological and political education of college students is the organization guarantee to strengthen socialist core value system education on college students. Universities should base on related requirements of the central government, clarify the duties and responsibilities of cadres of party and government and communist youth league cadre of the school, teachers of ideological and political theory course and philosophy and social science course, instructors and class teachers in socialist core value system education on college students, and form the work pattern of educating students through teaching, management and service. Secondly, establish and improve safeguard mechanism. Universities need to increase the input of funds in socialist core value system education and provide necessary place and equipment for it, continuously improve conditions and optimize means. Thirdly, establish and improve evaluation system. The effect of socialist core value system education on college students does not rest on the comment of a few college leaders or subjective feeling of some people simply. It is necessary to establish scientific evaluation criteria and deal with the proportion of dominant indicators and latent indicators. Besides, reward collectivity and individual that perform noticeably well in the process of socialist core value system education on college students and ascertain where the responsibility lies when misconduct appears.

\section{B. Scientifically Build Carrier of Socialist Core Value System Education on College Students}

To strengthen socialist core value system education on college students, we need to scientifically build carrier of education activity, let socialist core value system education close to college students' life and intensify the attraction and appeal of socialist core value system education. From the perspective of problems existing in socialist core value system education on college students, universities shall concentrate efforts on establishing advanced models, recreational and sports activities as well as public benefit activities. 
Firstly, establish advanced models. The strength of example is infinite. Universities shall establish advanced models that spread and practice socialist core value system among college students, in order to inspire and drive more students to carry forward socialist core value system. Universities must focus on two aspects in establishment of advanced models for college students: the first is to strengthen "own school oriented" of advanced models. In recent years, the national advanced models of college students such as Hong Zhanhui in Huaihua University, Shi Xiaodong in Lanzhou University have received extensive attention from the society because of their good deeds, which have set good examples for college students. National models are of course important for universities, but each university should establish advanced models in its own school, because it will influence college students more directly with stronger appeal. The second is to scientifically grasp the relation between morality and ability of advanced models. At present, many universities have set such advanced models as "Star of Self-improvement" and "Model Student". However, the selection standard of these advanced models mainly bases on scholastic attainment and neglects the "moral performance" of the candidates to a certain extent. Its negative effects cannot be ignored. The establishment of advanced models of college students should pay attention to the ability as well as morality.

Secondly, carry out corresponding recreational and sports activities. Most college students are 18 to 22 years old. They are full of youthful spirit with strong curiosity and like to participate in all kinds of recreational and sports activities. Universities should fully grasp the characteristics of college students and effectively use recreational and sports activities to carry out colorful socialist core value system education, teach through lively activities and enhance the attraction of socialist core value system education.

Thirdly, organize public benefit activities. Encourage college students to participate in public benefit activities, such as go to the countryside to support education with obligation, help stay-at-home children and the aged in gerocomium, serve as volunteers of important activities. It helps to solve the problems of public benefit as well as strengthen the sense of social responsibility and mission of college students, urge them to care for our country and the society. Now they enter universities to enrich knowledge and wisdom. In the future, they leave school to serve our country and the society.

\section{TEACHERS SHOULD TEACH STUDENTS BY PERSONAL EXAMPLE AS WELL AS VERBAL INSTRUCTION}

The relation between students and teachers is the most basic relationship among interpersonal relationships in universities. Every word and action of teachers deeply influences students. To carry out socialist core value education on college students, college teachers should firmly fulfill socialist core value system and set good example for students, meanwhile, guide students to inherit and fulfill socialist core value system.

\section{A. Teachers Should Actively Spread the Socialist Core Value} System

The socialist core value education on college students cannot realize through resounding slogan and fair-sounding language or several times of education. It is a "slow process". It takes ten years to grow a tree and a hundred years to bring up a generation of good men. Teachers should actively spread socialist core value system. They shall not only carry out socialist core value system education in class but also get to know students fully and solve ideology confusion that college students meet in their life.

Firstly, college teachers especially teachers of ideological and political course should correctly teach related knowledge of socialist core value system in class. Ideological and political course is the main channel of ideological and political education of college students and important ways to help students to establish right world outlook, outlook on life and values. At present, among four courses related to ideological and political education, the Mao Zedong Thought and Introduction to Theoretical System of Socialism with Chinese Characteristics and the Ideological and Moral Cultivation and Basic Law Education include contents of socialist core value system; the Marxist Philosophy Principle and the Outline of Modern Chinese History also have many contents related to socialist core value system. Teachers of ideological and political course should impart basic knowledge of socialist core value system to students through flexible teaching methods and let college students thoroughly understand the importance of building socialist core value system and correctly understand basic contents of socialist core value system as well as deeply grasp methods and ways to fulfill socialist core value system.

Secondly, college teachers should keep in contact with students after class and use socialist core value system to guide students to walk out of ideology confusion. Sukhomlinsky, the educationist of the Soviet Union thinks teachers are not only instructor of a discipline but also educator of students, advisor of students' life and guide of students' morality. When encountering problems related to world outlook, outlook on life and values, college students always communicate with teachers that they trust and hope teachers can help them to solve them. College teachers should build multilevel and diversified communication network between teachers and students according to this condition. The multilevel means teachers should consider different characters, problems and requirements of students and let each student can find proper channel to communicate with teachers. The diversified means the communication between teachers and students should not only keep the traditional methods but also open up new channels ceaselessly according to social development. In recent years, college students are inclined to rely on new media such as QQ, cornet, blogs, microblog, email and Qzone to communicate. Teachers should reasonably apply the new media to carry out timely, convenient and interactive communication with college students, help them to solve ideology confusions and promote their healthy growth. 


\section{B. Teachers Should Firmly Fulfill the Socialist Core Value System}

Whether college teachers can consciously fulfill socialist core value system directly influences the effect of socialist core value system education on college students. Teachers should firmly practice the socialist core value system to exert a subtle influence on college students' characters. Firstly, truly trust, learn and use the Marxism. The guiding thought of Marxism is the soul and theoretical basis of socialist core value system. It decides the property and direction of socialist core value system. Teachers should realize the Marxism is scientific theory, which reveals the law of human history development and indicates the direction of human development and social progress. The Marxism has not been "out of date" even "dead" as some people think. It is an open theoretical system and keeps pace with the times. It has strong vitality by receiving new blood and vigor continuously. Secondly, establish the common ideal of socialism with Chinese characteristics, which is the theme of socialist core value system. It expresses the yearning and pursuit of Chinese people for the great rejuvenation of China. The common ideal of socialism with Chinese characteristics closely connect national development, national rejuvenation with personal happiness. Just like other members of society, teachers should establish common ideal, have the entire motherland in mind and serve the people and strive to realize the common ideal. Thirdly, show good mental state and mental outlook. National spirit and spirit of the time are the essence of socialist core value system. Teachers should actively carry forward national spirit focusing on patriotism and spirit of the time focusing on reform and innovation, blaze new trails in a pioneering spirit, forge ahead with determination and keep vigorous mental state all the time to promote college students to burst out boundless creative spirit and creative vitality. Finally, improve moral cultivation. Socialist Concept of Honor and Disgrace is the basis of socialist core value system. It provides code of conduct for people. Teachers should consciously take "eight honors and eight disgraces" as reference, constantly improve their moral cultivation, show the charm of personality and influence others by goodness.

\section{College Students Should StRengthen SelF- EDUCATION}

Self-education is one of the fundamental ways of education of college students. Universities should guide and enlighten college students to carry out self-education, self-management and self-service. They shall intensify the self-education of college students on socialist core value system education. From the perspective of law of formation and development of values, the formation of the values of college students refers to the process that students "internalize" and "externalize" socialist core value system through cognition, thinking and practice. The school and the teacher are external causes. The self-education of college students is internal cause. External cause can only come into play via internal cause.

\section{A. Correctly Understand the Value of Socialist Core Value System and Internalize It}

Whether college students can give play to the zeal of selfeducation of socialist core value system has close relationship with the cognitive status of college students for socialist core value system. At present, under the influence of domestic and foreign new situation and new changes, some college students make their value orientation neutral, vague, market-oriented and confusing and lack political sensitivity and the ability to distinguish between right and wrong. The significant cause is that they cannot understand the value of socialist core value system on their healthy growth. They only treat the learning of socialist core value system as a task and lack internal impetus of self-education of socialist core value system. Students cultivated by universities are qualified builders and reliable successors of socialism with Chinese characteristics. College students should fully realize the socialist core value system is indispensable "nourishment for the mind" of them. Firstly, socialist core value system can help students to make a clear distinction between right and wrong in politics, take the firm political stand and consolidate political conviction, effectively resist bad interference of some western thoughts. Secondly, socialist core value system can help college students to form and insist on correct ideal and avoid the phenomena such as one with only moderate aspirations and goes with the stream. Thirdly, socialist core value system can make college students full of spirit and energy, positive, forge ahead with determination, full of youthful spirit and prevent them from being passive and decadent and wasting time. Finally, socialist core value system helps college students to establish correct concept of honor and disgrace, improve moral cultivation and perfect personality trait. College students should strengthen the initiative to learn and internalize socialist core value system.

\section{B. Actively Fulfill and Externalize Socialist Core Value System}

The purpose of students to "internalize" socialist core value system is to "externalize" it. College students should learn and apply socialist core value system with full vigor, use socialist core value system as guidance to analyze ideology confusion, interpret social problems and regulate their behavior.

1) Use socialist core value system to analyze ideology confusion: College students will meet various forms of ideology confusion in the process of growth. It is impossible for teachers to help all students to solve the confusion. It requires students consciously to take socialist core value system as the guidance, apply knowledge related to socialist core value system and analyze ideology confusion and the reason, find solution channel, suppress interference of wrong thinking and consolidate the Marxist world outlook, outlook on life and values.

2) Use socialist core value system to interpret social problems: College students do not live in the tower of ivory. They are deeply influenced by the overall social environment. How to analyze new situation and new change of the society directly influences the learning and life of college students. At present, in the process of social transformation of our country, the social trend of thought is complicated and changeable, such as the impact of the western thought of liberty, the spread of 
utilitarianism and personal hedonism as well as the prevailing extravagance. If college students cannot use scientific theory to analyze new situation and new change of the society, it will inevitably appear the phenomena that they lack political conviction and spirit with fuzzy values, which will impede their healthy growth. The socialist core value system provides "a golden key" for college students to interpret social problems. Therefore, college students should learn to use the "golden key" to analyze social problems and resist the temptation and impact of decadent ideas.

3) Use socialist core value system to regulate their behavior: The socialist core value system provides a basic value criterion and code of conduct for the members of society. It clearly tells people what they should insist on and advocate and what they should object and resist. College students should know black from white according to socialist core value system, clearly distinguish the good from the evil, promote righteousness as well as stop the bad and advocate the good.

\section{CONCLUSION}

At present, influenced by multiple effects of international and domestic factors, the situation faced by the construction of socialist ideology of universities becomes increasingly complicated and changeable. To ensure the socialist core value education on college students achieve ideal effect and cultivate them into builders and successors of the cause of socialism with Chinese characteristics, we must concentrate efforts on educational paths, urge universities, teachers and college students to form concerted effort and give full play to the overall effect of educational path.

\section{REFERENCES}

[1] Hu Jintao. Unswervingly Advance along the Path of Socialism with Chinese Characteristics, Strive for the Comprehensive Construction of the Well-off Society [M], Beijing: People's Publishing House, 2012

[2] Wang Gaohe. Tentative Analysis on the Construction of Socialist Core Value System [J], Party's History Literary World, 2008(20)

[3] Xu Zhigong. Intensify the Construction of Socialist Core Value System [J], Journal of Ideological and Theoretical Education, 2007(10)

[4] Wei Riping. Socialist Core Value System Is the Fundamental to Construct Harmonious Culture [J], Journal of Ideological and Theoretical Education, 2007(11)

[5] Chen Yajie. The Development and Formation of Connotation of the "Socialist Core Value System" [J], Shanghai Party's History and Party Building, 2007(2)

[6] Huang Zhao. Basic Contents and Elements Relationship of Socialist Core Value System [J], Studies in Ideological Education, 2007(7). 